УДК 351.87

https://doi.org/10.52058/2708-7530-2021-9(15)-162-171

Мукан Іван Васильович аспірант кафедри управління та бізнесадміністрування, ДВНЗ «Прикарпатський національний університет імені Василя Стефаника», вул. Шевченка, 57, м. Івано-Франківськ, 76018, тел.: (067) 92596 55, e-mail: ab.ivannalog@i.ua, ivannalog@gmail.com, https://orcid.org/0000-0003-3233-7903

Шикеринець Василь Васильович кандидат наук з державного управління, доцент, завідувач кафедри управління соціокультурною діяльністю, шоу-бізнесу та івентменеджменту, заступник декана факультету туризму з наукової роботи, ДВНЗ «Прикарпатський національний університет імені Василя Стефаника», вул. Шевченка, 57, м. Івано-Франківськ, 76018, тел.: (095) 4239468, e-mail: vasyl.shykerynets@pnu.edu.ua, https://orcid.org/0000-0002-6845-1639.

\title{
ЗАХОДИ ЗАГАЛЬНОГО ХАРАКТЕРУ В МЕХАНІЗМІ ВИКОНАННЯ РІШЕНЬ ЄВРОПЕЙСЬКОГО СУДУ 3 ПРАВ ЛЮДИНИ: ДЕРЖАВНО- УПРАВЛІНСЬКИЙ АСПЕКТ
}

Анотація. Україна активно інтегрується у Європейський Союз та імплементує європейські цінності щодо захисту прав людини та основоположних свобод. В Україні значного поширення набула практика звернення до Європейського суду 3 прав людини. Головним критерієм ефективності дії системи Конвенції про захист прав людини та основоположних свобод $\epsilon$ виконання рішень Європейського суду з прав людини. Національний механізм виконання рішень Європейського суду 3 прав людини передбачає ефективне забезпечення виконання заходів загального характеру викладених у рішеннях ЄСПЛ. Стаття піднімає проблему одночасно сфери публічного управління, юриспруденції та соціального захисту. У статті розглянуто особливості суб'єктного складу механізмів виконання рішень ЄСПЛ та виконання заходів загального характеру в Європейських країнах - Великобританії, Німеччині, Чеській Республіці та Словацькій Республіці. Проаналізовано особливості суб'єктного складу механізму виконання рішень суду в Україні, які розкриті у контексті виконання заходів загального характеру. Розглянуто функції національних суб'єктів механізму виконання рішень Свропейського суду з прав людини щодо виконання заходів загального характеру на національному рівні. Проаналізовано проблеми які існують у сфері виконання заходів загального характеру, викладених у рішеннях Європейського суду з прав людини в Україні на рівні законодавчого, інституційного та функціонального забезпечення. Запропоновано заходи з підвищення ефективності та вдосконалення механізму виконання рішень Європейського суду з прав людини в Україні, зокрема 
створення парламентської інституції 3 широкими повноваженнями парламентського контролю та координації діяльності органів виконавчої влади, прокуратури та національних судів. Новоствореній інституції запропоновано надати право законодавчої ініціативи у зв'язку 3 виконання рішень Європейського суду 3 прав людини щодо виконання заходів загального характеру, повноваження розробляти спеціальні організаційно-правові засоби виконання рішень Європейського суду 3 прав людини, ініціювати відповідальність державних органів та їхніх посадових осіб за невиконання та неналежне виконання рішень Свропейського суду з прав людини.

Ключові слова: Конвенція про захист прав людини та основоположних свобод та протоколи до неї (конвенція); Свропейський суд 3 прав людини (ЄСПЛ); Комітет міністрів Ради Свропи; механізм виконання рішень Європейського суду з прав людини; заходи загального характеру; уповноважений у справах Європейського суду з прав людини; суб'єкти державного управління.

Mukan Ivan Vasyliovych Graduate student of the Department of Management and Business Administration, Vasyl Stefanyk Precarpathian National University, 76018, Ivano-Frankivsk, Shevchenka St., 57, tel.: (067) 92596 55, e-mail: ab.ivannalog@i.ua,ivannalog@gmail.com, https://orcid.org/0000-0003-3233-7903

Shikerynets Vasyl Vasyliovych Candidate of Sciences in Public Administration, Associate Professor, Head of the Department of Socio-Cultural Activity Management, Show Business and Event Management, Deputy Dean of the Faculty of Tourism for Research, Vasyl Stefanyk Precarpathian National University, Shevchenka St., 57, Ivano-Frankivsk, 76018, tel.: (095) 4239468, e-mail: vasyl.shykerynets@pnu.edu.ua, https://orcid.org/0000-0002-6845-1639.

\title{
GENERAL MEASURES IN THE MECHANISM OF ENFORCEMENT OF JUDGMENTS OF THE EUROPEAN COURT OF HUMAN RIGHTS: PUBLIC ADMINISTRATION ASPECT
}

\begin{abstract}
Ukraine is actively integrating into the European Union and implementing European values for the protection of human rights and fundamental freedoms. In Ukraine, the practice of appealing to the European Court of Human Rights has become widespread. The main criterion for the effectiveness of the system of the Convention for the Protection of Human Rights and Fundamental Freedoms is the implementation of the decisions of the European Court of Human Rights. The national mechanism for the enforcement of judgments of the European Court of Human Rights provides for the effective enforcement of measures of a general nature set out in judgments of the European Court of Human Rights. The article raises the issue of public administration, jurisprudence and social protection at the same time. The article considers the peculiarities of the subjective composition of the mechanisms
\end{abstract}


of implementation of ECHR decisions and the implementation of general measures in European countries - Great Britain, Germany, the Czech Republic and the Slovak Republic. The peculiarities of the subjective composition of the mechanism of execution of court decisions in Ukraine, which are revealed in the context of the implementation of general measures, are analyzed. The functions of national subjects of the mechanism of execution of the decisions of the European Court of Human Rights on the implementation of general measures at the national level are considered. The problems that exist in the field of implementation of general measures set out in the decisions of the European Court of Human Rights in Ukraine at the level of legislative, institutional and functional support are analyzed. Measures are proposed to increase the efficiency and improve the mechanism for implementing the decisions of the European Court of Human Rights in Ukraine, including the establishment of a parliamentary institution with broad powers of parliamentary control and coordination of executive bodies, prosecutors and national courts. The newly established institution is proposed to give the right of legislative initiative in connection with the implementation of the decisions of the European Court of Human Rights on the implementation of general measures, the power to develop special organizational and legal means to implement the decisions of the European Court of Human Rights. and improper enforcement of judgments of the European Court of Human Rights.

Keywords: Convention for the Protection of Human Rights and Fundamental Freedoms and its protocols (convention); European Court of Human Rights (ECHR); Committee of Ministers of the Council of Europe; mechanism for implementing the decisions of the European Court of Human Rights; general measures; Commissioner for the European Court of Human Rights; subjects of public administration.

Постановка проблеми. Україна активно інтегрується у Європейський Союз та імплементує у національне законодавство європейські цінності щодо захисту прав людини та основоположних свобод. Система Конвенції про захист прав людини та основоположних свобод через рішення Європейському суду з прав людини (ССПЛ) впроваджує практику розуміння та захисту прав людини та основоположних свобод у правові системи держав-учасниць конвенції, допомагає державам-членам Конвенції виявляти системні проблеми щодо захисту прав людини та пропонує шляхи їх вирішення. Заходи загального характеру є інструментом за допомогою якого правові системи держав-учасниць конвенції впроваджують європейські цінності щодо захисту прав людини та основоположних свобод закріплені у Конвенції. Ефективне виконання заходів загального характеру сприяє оздоровленню і трансформація правової системи України, наближення іiі до стандартів ЄСПЛ, визначених у практиці ЄСПЛ та Комітету міністрів Ради Свропи.

Аналіз останніх досліджень і публікацій. Питанню виконання рішень ЄСПЛ, а також імплементації та застосування практики суду присвячені праці
К. Андріанова,
В. Завгороднього,
В. Капустинського,
С. Кивалов, 
О. Андрейченка, М. Сащенко, О. Чернецької, Я. Пасічника, П. Рабіновича, Н. Севостянової, Ю. Хім'яка, Б. Мукан, Н. Блажівської, М. Хилько Г Зубенко та ін. Недостатньо дослідженим залишилось питання виконання заходів загального характеру, як складової механізму виконання рішень ЄСПЛ.

Мета статті - удосконалення функціональності національних суб'єктів державного управління у механізмі виконання рішень ЄСПЛ щодо виконання заходів загального характеру. Для досягнення мети потрібно вирішити такі завдання: проаналізувати механізм виконання рішень ЄСПЛ щодо виконання заходів загального характеру у європейських країнах та Україні і виокремити особливості у механізмі виконання рішень суду щодо заходів загального характеру в Україні; обгрунтувати заходи 3 підвищення ефективності та вдосконалення механізму виконання рішень ЄСПЛ щодо заходів загального характеру в Україні.

Викладення основного матеріалу. Механізм захисту прав людини згідно Конвенції діє шляхом винесення ЄСПЛ індивідуальних та пілотних рішень у справах за зверненнями приватних осіб чи неурядових організацій або груп осіб. Держави-учасниці конвенції зобов'язуються виконувати остаточні рішення Суду в будь-яких справах, у яких вони $є$ сторонами [1]. Під виконанням рішень ССПЛ слід розуміти виплату відшкодування, вжиття додаткових заходів індивідуального характеру та вжиття заходів загального характеру. Під вжиттям заходів загального характеру слід розуміти заходи, що застосовуються з метою забезпечення дотримання Державою положень Конвенції, порушення яких встановлене рішенням ЄСПЛ, забезпечення усунення недоліків системного характеру, що лежать в основі виявленого ЄСПЛ порушення, а також усунення підстави для надходження до ССПЛ заяв проти Держави, спричинених проблемою, яка вже була предметом розгляду в ССПЛ.

Виконання державами - учасницями рішень ЄСПЛ щодо вжиття заходів загального характеру забезпечують три ключові конвенційні суб'єкти Європейський суд з прав людини (ССПЛ), Комітет міністрів (КМ) та Мережу вищих судів (SCN), які діють узгоджено та доповнюють один одного. Для належного виконання рішень ЄСПЛ механізм Конвенції передбачає також обов'язкову наявність внутрідержавних суб'єктів механізму виконання рішень суду держав-учасниць Конвенції [2].

У парламенті Великобританії функціонує об'єднаний комітет 3 прав людини, що складається 3 дванадцяти членів, призначених як 3 палати громад, так і з палати лордів, які розглядають питання, пов'язані 3 правами людини у Великобританії. Робота Комітету включає вивчення кожного урядового законопроекту щодо його сумісності з правами людини. Комітет також уважно вивчає реакцію уряду на судові рішення, що стосуються прав людини, та дотримання Великобританією своїх зобов'язань з прав людини, що містяться в цілому ряді міжнародних договорів [3].

В Німеччині в системі Федерального міністерства юстиції та захисту прав

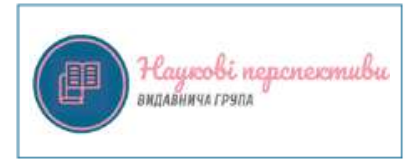


споживачів діє Управління Уповноваженого федерального уряду з прав людини Німеччини, яке здійснює моніторинг виконання рішень Європейського суду 3 прав людини і щорічно готує та подає до бундестагу письмові звіти щодо прецедентного права: про судову практику Європейського суду з прав людини і реалізацію його рішень у справах проти Німеччини та про судову практику Європейського суду з прав людини і реалізацію його рішень у справах проти інших країн за участю Німеччини [4].

В Чеській Республіці у складі міністерства юстиції Чеської Республіки діє Урядового представника Чеської Республіки в Європейському суді 3 прав людини який, зокрема: формує концепцію заходів, необхідних для виконання рішень Європейського суду 3 прав людини, включаючи законодавчі зміни, пропонує процедуру їх втілення і координує зауваження Комітету міністрів по цим заходам та вживає інші заходи загального характеру [5]. Дорадчим органом уповноваженим урядом представляти Чеську Республіку перед ЄСПЛ є Колегія експертів 3 питань виконання рішень Європейського суду 3 прав людини та імплементації Конвенції про захист прав людини та основних свобод. Колегія складається 3 представників усіх міністерств, обох палат парламенту Чеської Республіки, Верховних судів, прокуратури, Управління громадського захисника прав, наукових кіл та громадянського суспільства. Перше засідання Колегії відбулося 10 листопада 2015 року. Колегія збирається відповідно до рішень ЄСПЛ, як правило, раз на 6-12 місяців. Завдання Колегії полягає в аналізі рішень ЄСПЛ, винесених у процесі проти Чеської Республіки, та формуванні рекомендацій компетентним органам щодо прийняття загальних заходів для виконання цих рішень, що попередить повторні подібні порушення Конвенції в майбутньому. Метою діяльності Колегії є сприяння ефективному виконанню рішень ЄСПЛ та підвищення обізнаності компетентних органів про зобов'язання, що виникають для Чеської Республіки згідно з Конвенцією. Інша мета полягає у застосуванні Конвенції та практики ССПЛ у повсякденній практиці національних органів влади i, зрештою, у повній мірі реалізації основних прав і свобод, закріплених у Конвенції та Додаткових протоколах до неї [6]. В Чехії також діє неурядова академічна організація - Чеський центр з прав людини та демократії, яка зосереджується на неупередженому професійному дослідженні тем, що стосуються захисту прав людини. Центр відрізняється як від неурядових установ, так і від державних установ, що працюють у цій галузі. Центр - це незалежна академічна установа, яка здійснює моніторинг прав людини 3 професійної соціальної науки та міжнародно-правової точки зору. Центр є членом Інститутів прав людини (Асоціація інститутів прав людини). AHRI - це міжнародна асоціація провідних дослідницьких установ 3 прав людини. Центр спеціалізується поряд з іншим у напрямках: європейська система захисту прав людини; міжнародна політика, бізнес і права людини; Чеська Республіка і права людини [7].

У Словацькій Республіці в складі Міністерства юстиції діс Канцелярія 
Представника Словацької Республіки в Європейському суді з прав людини. Відповідно до Організаційного кодексу 12/2016 Міністерства юстиції Словацької Республіки від 28 квітня 2016 р. № 41557/2016/100 поряд 3 іншими повноваженнями забезпечує і контролює належне виконання рішення суду; щорічно подає звіт уряду Словацької Республіки через Міністра про свою діяльність. Представник Словацької Республіки у співпраці з Міністерством закордонних справ і європейських справ Словаччини звітує Комітету міністрів Ради Європи щодо виконання рішення Європейського суду з прав людини i розвиток верховенства права і свобод людини в Словацькій Республіці; представляє Міністру пропозиції про вжиття заходів щодо усунення повторюваних порушення Конвенції [8]. Законом Національної ради Словацької Республіки №. 308/1993 Coll. «Про створення Словацького національного центру 3 прав людини» створено Словацький національний центр 3 прав людини, який являється незалежним Національним інститут 3 прав людини, 3 широкими повноваженнями щодо захисту і заохочення прав людини в країні. Національний інститут 3 прав людини забезпечує належне відображення міжнародних зобов'язань Словацької республіки в галузі прав людини в національному законодавстві. Повноваження інституту дозволяють співпрацювати 3 деякими органами ООН, Ради Європи та Європейського Союзу [9].

В Україні питання, пов'язані з виконанням рішень ССПЛ врегульовані Законом України «Про виконання рішень та застосування практики Європейського суду з прав людини» від 23 лютого 2006 року [10].

Відповідно до українського законодавства до заходів загального характеру віднесено внесення змін до чинного законодавства та практики його застосування, внесення змін до адміністративної практики, забезпечення юридичної експертизи законопроектів, забезпечення професійної підготовки 3 питань вивчення Конвенції та практики Суду - прокурорів, суддів, адвокатів та інших правоохоронних органів, інші заходи, які визначаються з боку Комітету міністрів Ради Свропи.

Діяльність щодо координації виконанням рішень ЄСПЛ покладена на Уповноваженого у справах Європейського суду з прав людини, який за посадою $\epsilon$ заступником міністра юстиції України. Діяльність Уповноваженого у справах Європейського суду 3 прав людини забезпечується Секретаріатом Уповноваженого у справах Європейського суду з прав людини, структурним підрозділом Мін'юсту, яке очолює керівник Секретаріатом Уповноваженого у справах Європейського суду з прав людини. [11]

Виконання заходів загального характеру забезпечує Кабінет Міністрів України, Прем'єр-міністр визначає центральні органи виконавчої влади, які $€$ відповідальними за виконання заходів загального характеру та надає їм відповідні доручення. Центральний орган виконавчої влади в межах своєї компетенції видає відомчі акти на виконання заходів загального характеру та контролює їх виконання, вносить до Кабінету Міністрів України пропозиції щодо 
прийняття нових, скасування чинних нормативно-правових актів або внесення до них змін. Кабінет Міністрів України забезпечує видання в межах своєї компетенції актів на виконання заходів загального характеру, вносить у порядку законодавчої ініціативи до Верховної Ради України законопроекти щодо прийняття нових, скасування чинних законів або внесення до них змін.

29 серпня 2019 року у Верховній Раді України 9 скликання створений підкомітет з питань виконання рішень ЄСПЛ та альтернативного розв'язання спорів Комітету з питань правової політики. Згідно $з$ додатком до Постанови Верховної Ради України від 29 серпня 2019 року № 19-IX «Про перелік, кількісний склад і предмети відання комітетів Верховної Ради України дев'ятого скликання» до завдань комітету належить засади організації виконання рішень ЕСПЛ [12].

Станом на жовтень 2020 р. Свропейським судом 3 прав людини було ухвалено 1619 рішень, якими констатовано порушення Україною положень Конвенції про захист прав людини і основоположних свобод та Протоколів до неї, та які передані для нагляду за їхнім виконанням до Комітету міністрів Ради Свропи. Станом на жовтень 2020 року по 1045 рішеннях Комітетом Міністрів прийнято резолюції про їх остаточне виконання [13]. Більшість невиконаних рішень ЄСПЛ стосується невиконання саме заходів загального характеру.

Зазвичай відповідачами за заявами, поданими до Європейського суду з прав людини стають держави, які мають проблеми із якістю роботи судової системи та з довірою до неї з боку громадян. Станом на 31 грудня 2019 р., відповідачами по більш, ніж 2/3 поданих до ЄСПЛ заяв були чотири держави: Росія (15 050 заяв, що становить 25,2 \% від загальної кількості справ, які перебувають на розгляді в ЄСПЛ), Туреччина (9250 заяв, 15,5 \% від загальної кількості), Україна (8850 заяв, 14,8 \% від загальної кількості), Румунія (7900 заяв, що становить 13,2% від загальної їх кількості) [14]. Спостерігається динаміка до збільшення поданих заяв в ССПЛ у 2019 році (8850 заяв, 14,8 \% від загальної кількості) проти у 2018 (7250 заяв, 12,9 \% від загальної кількості) та у 2017 році (7250 заяв, 12,6 \% від загальної кількості).

Комітет з юридичних питань та прав людини Парламентської асамблеї Ради Європи у своїй доповіді «Забезпечення життєздатності Страсбурзького суду: структурні недоліки в державах-учасницях» пропонує розширити повноважень парламентських комітетів із правових питань (правосуддя) відповідних державучасниць, а саме - надати цим комітетам право «контролювати діяльність органів виконавчої влади, відповідальних за виконання рішень Європейського суду 3 прав людини, розробляти спеціальні засоби (організаційні та правові), впливати на уряди держав-учасниць у зв’язку з порушеннями, що відбуваються, зокрема у разі затримки виконання рішень Страсбурзького суду» [15].

Очевидна необхідність підвищення ролі національних парламентів 3 контролю за виконанням рішень Європейського суду 3 прав людини. Парламентським комітетам з правових питань (правосуддя) відповідних держав- 
учасниць «повинні бути надані повноваження: контролювати діяльність органів виконавчої влади, відповідальних за виконання судових рішень Європейського суду 3 прав людини, розробляти спеціальні засоби, організаційні і правові, впливати на уряди держав-учасників у зв'язку з порушеннями, що відбуваються, зокрема, у разі затримки виконання рішень Європейського суду з прав людини».

Висновки: Національний механізм виконання заходів загального характеру, викладених у рішеннях ЄСПЛ, як показує практика, недостатньо ефективний, що призводить до повного чи часткового невиконання рішень ЄСПЛ.

3 метою збільшення ефективності національного механізму виконання рішень ЄСПЛ для управління та координації процесу виконання рішень ЄСПЛ в Україні варто створити постійно діючий комітет Верховної ради України 3 широкими повноваженнями щодо координації та контролю діяльності органів виконавчої влади, прокуратури та національних судів. До повноважень комітету варто включити вивчення законопроектів та проектів урядових нормативноправових актів, з обов'язковим наданням висновку щодо його сумісності 3 правами людини та практикою ЄСПЛ. Йому доцільно надати право законодавчої ініціативи у зв'язку з виконання рішень ССПЛ щодо виконання заходів загального характеру, повноваження розробляти спеціальні організаційно-правові засоби виконання рішень ЄСПЛ, ініціювати відповідальність державних органів та їхніх посадових осіб за невиконання та неналежне виконання рішень ЄСПЛ.

\section{Лimepamypa:}

1. Конвенція про захист прав людини і основоположних свобод, ратифікована Україною 17.07.1997 року. URL: https://zakon.rada.gov.ua/laws/show/995_004 (дата звернення 21.09.2021).

2. Мукан I.B Інституційно-правові особливості функціонування суб'єктів державного управління з питань виконання рішень Свропейського суду з прав людини в Україна // Вчені записки Таврійського Національного університету імені В.I. Вернадського. Серія: Державне управління, Том 31 (70) № 6 2020, с.58-65.

3. UK Parliament, Joint Committee on Human Rights. URL: https://committees.parliament.uk/ committee/93/human-rights-joint-committee/role/ (дата звернення: 21.09.2021).

4. Офіційний веб-сайт Федерального міністерства юстиції та захисту прав споживачів. URL:http://www.bmjv.de/DE/Themen/Menschenrechte/EntscheidungenEGMR/EntscheidungenEGM R_node.html.(дата звернення: 21.09.2021).

5. Př́lloha II k Organizačnímu řádu Ministerstva spravedlnosti č. j. MSP-61/2017-ORLZORG/24. URL : https://portal.justice.cz/Justice2/MS/ms.aspx?j=33\&o=23\&k=5840\&d=184430 (дата звернення: 21.09.2021).

6. Ministerstva spravedlnosti čr. Kolegium experti̊ $\mathrm{k}$ výkonu rozsudků ESLP. URL: https://www.justice.cz/web/msp/kolegium-expertu-k-vykonu-rozsudku-eslp (дата звернення: 21.09.2021).

7. Czech Centre for Human Rights and Democratization. URL : https://www.centrumlidskaprava.cz/kdo-jsme-co-delame-0 (дата звернення: 21.09.2021).

8. Organizačný poriadok 12/2016. URL : http://www.justice.gov.sk/ZbierkaInstrukciiAOznameni/ 12_2016/OP 12_2016.pdf (дата звернення: 21.09.2021).

9. Slovenske narodne stredisko pre ludske prava. URL : http://www.snslp.sk/\#page=2478 (дата звернення: 21.09.2021).

10. Про виконання рішень та застосування практики Європейського суду з прав людини:

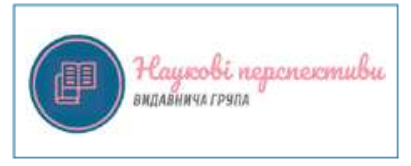


Закон України. URL:http://zakon2.rada.gov.ua/laws/show/3477-15 (дата звернення: 21.09.2021).

11. Мукан I.B Інституційно-правові особливості функціонування суб'єктів державного управління з питань виконання рішень Європейського суду з прав людини в Україна // Вчені записки Таврійського Національного університету імені В.І. Вернадського. Серія: Державне управління, Том 31 (70) № 6 2020, с.58-65.

12. Про перелік, кількісний склад і предмети відання комітетів Верховної Ради України дев'ятого скликання, Постанова Верховної Ради України. URL: https://zakon.rada.gov.ua/laws/main/19-IX (дата звернення: 21.09.2021).

13. Committee of Ministers. Department for the execution of judgments of the European Court of Human Rights. Country Factsheet. Ukraine. URL: https://rm.coe.int/1680709769 (дата звернення: 21.09.2021).

14. European Court of Human Rights. Analysis of statistics 2019. January 2020. URL: https://www.echr.coe.int/Documents/Stats_analysis_2019_ENG.pdf (дата звернення: 21.11.2020).

15. Ківалов С. В. Міжнародно-правові та національні механізми удосконалення виконання рішень та застосування практики Свропейського суду з прав людини // Матеріали другої міжнародної науково-практичної конференції, присвяченої 60-річчю набуття чинності Конвенції про захист прав людини і основоположних свобод 1950 року, що проводиться під егідою Генерального секретаря Ради Європи пана Турбйорна Ягланда (Одеса, 20 - 21 вересня 2013 р.). Одеса : ПП “Фенікс”, 2013. С. 27.

\section{References:}

1. Convention for the Protection of Human Rights and Fundamental Freedoms, Rome, 4.XI.1950, Retrieved from https://zakon.rada.gov.ua/lavs/shov/995_004 [in Ukrainian].

2. Mukan I.V (2020) Instytutsijno-pravovi osoblyvosti funktsionuvannia sub'iektiv derzhavnoho upravlinnia z pytan' vykonannia rishen' Yevropejs'koho sudu z prav liudyny v Ukraina [Institutional and legal features of the functioning of public administration entities on the implementation of the decisions of the European Court of Human Rights in Ukraine]. Vcheni zapysky Tavrijs'koho Natsional'noho universytetu imeni V.I. Vernads'koho. Seriia: Derzhavne upravlinnia, Vol. 31 (70), 6, 58-65 [in Ukrainian].

3. UK Parliament, Joint Committee on Human Rights. Retrieved from: https://committees.parliament.uk/committee/93/human-rights-joint-committee/role/ [in United Kingdom].

4. Federal'ne ministerstvo iustytsii ta zakhystu prav spozhyvachiv [Federal Ministry of Justice and Consumer Protection]. Retrieved from: http://www.bmjv.de/DE/Themen/Menschenrechte/ EntscheidungenEGMR/EntscheidungenEGMR_node.html [in Germany].

5. Př́loha II k Organizačnímu řádu Ministerstva spravedlnosti č. j. MSP-61/2017-ORLZORG/24. [Annex II to the Organizational Rules of the Ministry of Justice No. MSP-61/2017-ORLZORG / 24.] Retrieved from : https://portal.justice.cz/Justice2/MS/ms.aspx .j=33\&o=23\&k=5840\&d= 184430 [in Czech Republic]

6. Ministerstva spravedlnosti čr. Kolegium expertů k výkonu rozsudků ESLP [Ministry of Justice of the Czech Republic College of Experts on the Enforcement of ECtHR Judgments]. Retrieved from: https://www.justice.cz/web/msp/kolegium-expertu-k-vykonu-rozsudku-eslp. [in Czech Republic].

7. Czech Centre for Human Rights and Democratization. Retrieved from : https://www.centrumlidskaprava.cz/kdo-jsme-co-delame-0. [in Czech Republic].

8. Organizačný poriadok 12/2016 [Organizational rules 12/2016.] Retrieved from http://www.justice.gov.sk/ZbierkaInstrukciiAOznameni/12_2016/OP 12_2016.pdf. [in Slovak Republic].

9. Slovenske narodne stredisko pre ludske prava [Slovak National Center for Human Rights]. Retrieved from : http://www.snslp.sk/\#page=2478. [in Slovak Republic].

10. Zakon Ukrainy «Pro vykonannia rishen' ta zastosuvannia praktyky Yevropejs'koho sudu z prav liudyny» [Law of Ukraine "On Enforcement of Judgments and Application of the Case Law of 
the European Court of Human Rights"]. Retrieved from:http://zakon2.rada.gov.ua/laws/show/3477-15 [in Ukrainian].

11. Mukan I.V (2020) Instytutsijno-pravovi osoblyvosti funktsionuvannia sub'iektiv derzhavnoho upravlinnia z pytan' vykonannia rishen' Yevropejs'koho sudu z prav liudyny v Ukraina [Institutional and legal features of the functioning of public administration entities on the implementation of the decisions of the European Court of Human Rights in Ukraine]. Vcheni zapysky Tavrijs'koho Natsional'noho universytetu imeni V.I. Vernads'koho. Seriia: Derzhavne upravlinnia, Vol. 31 (70), 6, 58-65 [in Ukrainian].

12. Postanova Verkhovnoi Rady Ukrainy «Pro perelik, kil'kisnyj sklad i predmety vidannia komitetiv Verkhovnoi Rady Ukrainy dev'iatoho sklykannia» [Resolution of the Verkhovna Rada of Ukraine "On the List, Quantitative Composition and Subjects of the Committees of the Verkhovna Rada of Ukraine of the Ninth Convocation"]. Retrieved from: https://zakon.rada.gov.ua/laws/main/19IX [in Ukrainian].

13.Committee of Ministers. Department for the execution of judgments of the European Court of Human Rights. Country Factsheet. Ukraine. Retrieved from: https://rm.coe.int/1680709769. [in Ukrainian].

14. European Court of Human Rights. Analysis of statistics 2019. January 2020. Retrieved from: https://www.echr.coe.int/Documents/Stats_analysis_2019_ENG.pdf. [in Ukrainian].

15. Kivalov, S. V. (2013). Mizhnarodno-pravovi ta natsional'ni mekhanizmy udoskonalennia vykonannia rishen' ta zastosuvannia praktyky Yevropejs'koho sudu z prav liudyny [International legal and national mechanisms for improving the implementation of decisions and application of the case law of the European Court of Human Rights]. Proceedings of the Second International Conference on the 60th Anniversary of the entry into force of the 1950 Convention on the Protection of Human Rights and Fundamental Freedoms, held under the auspices of the Council of Europe Secretary General, Mr Thorbjrn Jagland, 20 - 21 veresnia 2013 r. Odesa : PP "Feniks", 27 [in Ukrainian]. 